\title{
Opting for Migration: Is it Just an Economic Necessity?-A Comparison between German and Polish Highly Skilled Graduates
}

\author{
Alexandra David ${ }^{1}$, Anna Barwińska-Małajowicz ${ }^{2}$ \\ ${ }^{1}$ Institute for Work and Technology, Westfälische Hochschule, Gelsenkirchen, Germany \\ ${ }^{2}$ University of Rzeszów, Faculty of Economic Sciences, Rzeszów, Poland \\ Correspondence: Alexandra David, Institute for Work and Technology, Westfälische Hochschule, Munscheidstr. 14, \\ 45886 Gelsenkirchen, Germany
}

Received: January 20, 2015

Accepted: February 3, 2015 Online Published: February 12, 2015

doi:10.11114/jets.v3i2.678

URL: http://dx.doi.org/10.11114/jets.v3i2.678

\begin{abstract}
This paper deals with the migration motives of German and Polish final semester students and university graduates in the partner cities of Bielefeld (GER) and Rzeszów (PL), who are on the threshold of their professional careers. The survey presented here was motivated by the question: are the current migration motives of highly-skilled graduates still economically driven or have migration motives changed due to the increasing education level of migrants and new migration patterns, and will be described in this article. The survey provides insights into emigration destinations favoured by graduates from the two cities. In addition, the importance of informal networks for a migration-related job search was analysed. The survey's accomplished results contribute, at a micro-level, to the broad literature and to migration theories at macro and meso-level. In times of high (youth) unemployment in several European regions as well as skills shortages and demand for highly-skilled workers in other European regions, new approaches on migration motives are required. The content of this study can help destination countries and regions reflect on their attraction strategy for highly-skilled workers and set new incentives based on an individual view.
\end{abstract}

Keywords: economic migration necessity, graduates, highly skilled, migration motives

\section{Introduction}

\subsection{Problem Description}

Humans have always been mobile and moved abroad searching for new opportunities and better lifestyles (Castles et al., 2014). In Europe especially, both human mobility and migration have a long tradition. Before the two World Wars, Europe was considered a continent of emigration rather than immigration. In the 1950s, a change in migration flows occurred. Europe was chosen by a large number of immigrants from former colonial states and became an immigration continent. Moreover, western European countries in particular, suffered a lack of workforce due to the fast growing economy after World War II. This fast development in the fields of economy, welfare, lifestyle, political and social security etc. (Gans et al., 2013) motivated further people to emigrate to and within Europe leading to a long-term chain migration. Since then, migrants have belonged to European life and its street scene (Yildiz, 2013). In the past few years, migration in Europe has increased again and has become an even stronger persistent factor of the European economy (OECD, 2013; OECD, 2014). Effects of the aforementioned financial and economic crises, internationalisation, as well as the promotion of free movement within the EU, have led to new migration patterns, pluralisation and globalisation of migration (Castles \& Miller, 2009). The new migration patterns differ in several features from those previously, mostly in the time and the place dimension. Whereas in Europe between 1970 and 1990 people tended to be permanent or long-term migrants moving bilaterally between a domestic and receiving country, the later and current situation shows a tendency to temporary and circular migration (Nowicka, 2007). It seems as if permanent migration rebounds (OECD, 2014). In addition, it is observed that since the late 1990s, new forms of migration patterns have solidified. David et. al (2012) refer to these as "New Nomads" inspired by the concept of Saxenian's "New Argonauts" (2007). Usually this involves mostly highly-skilled migrants. "New Nomads" stand out by choosing multiple destination countries, moving from one region to another within a certain period of time. They live transnationally (Pries, 2013) including undertaking return migration to their domestic region and emigrating anew. (Klagge \& Klein-Hitpaß, 2010). This underlines how, in addition to a transformed time and space dimension, there is also a change in the sort of people who are migrating 
(OECD, 2014). Although "new" migrants are better educated and more mobile than the previous generation, this does not mean that every case has a success story to offer. Even when there is a demand for educated people in several European countries, which is known as skills shortage, many migrants still do not have the adequate entrance requirements for the labour markets of the receiving countries. Moreover, they fight challenges of inclusion such as the recognition of their qualifications and/or language skills (OECD, 2014). In turn, even highly-skilled migrants have to deal with uncertainties, which are increased by globalisation effects. This makes their migration choices harder rather than easier. As there is an increasing demand for highly-skilled workers, it is of prime importance to know which motives drive highly educated people to migrate. In knowing this, countries and regions can set incentives to influence migration choice and increase their attractiveness.

\subsection{Relevant Scholarship and Paper's Hypotheses}

The long tradition of migration has been captured in several studies. Among them are studies considering migration as an overall phenomenon (Castles et al., 2014; Bade, 2003; King, 1978), studies on the influence of return migration (Klagge \& Klein-Hitpaß, 2010; Saxenian, 2007), studies on migration networks and chain migration (Haug, S., 2008; Faist, 2007; Pries, 2001), studies on the choice of migration (Haisch \& Klöpper 2014; Haug, 2008) and/or migration processes (Massey et al., 1998; Lee, 1966). Further pillars of migration research are studies of highly-skilled workers (David \& Coenen, 2014; Salt, 2009) and their migration motives (Verwiebe at al., 2010). The research interest in this group has been mainly dealt with within the context of the brain drain/brain gain discussion (David \& Coenen, 2014; Stockhorst, 2011). The concept behind this so-called brain flows discussion follows the presumption that highly skilled workers are drivers of regional innovation by influencing the regional knowledge base though individual skills and higher degrees (David \& Coenen, 2014; David et al., 2012; Faggian \& McCann 2009; Florida, 2008). They tend to have important impacts on knowledge creation and diffusion (OECD, 2008).

By following this theme, this article contributes to the acknowledgement of migration motives of young, highly-skilled people. In this case, the article focuses on university graduates. The survey presented here follows the logic of studying prospective migration processes and their motives. Therefore, it is of a hypothetical nature, contrary to many other surveys, which regard migration processes and their motives retrospectively. This survey aligns with other studies such as Vorwiebe et al. (2010), which also consider a planned migration process instead of one accomplished. This survey concentrates on university graduates from two cities, both located in Europe and characterized by migration: Rzeszów (southeast Poland) and Bielefeld (East Westphalia, Germany). Initially, the study was motivated by the fact that migration between Poland and Germany has not decreased in the last decades, as once supposed. Even though Poland has been an EU member state since 2004, Polish people are still migrating in large numbers and make up the biggest group of all immigrants in Germany (OECD, 2014).

Following the argumentation above, the survey was driven by the following questions:

1. Have migration motives changed over the last decades regarding highly-skilled graduates from Poland and Germany? The question was inspired by an assumption based on several migration theories (see chapter 2), which argue that migration is predominantly driven by economics. In this context, several studies refer to low-skill migration (Wagner et al., 2013). Due to current migrants' higher qualification levels, phenomena such as the Bologna Reform and the opening of borders and free movement of workers, the authors presumed a change in migration motives with movement away from solidly economically driven migration.

2. Do highly-skilled migrants opt for new destination countries when searching for a job or do they follow a kind of path dependence in their choice of destination? The assumption was that historical migration roots/paths such as between Poland and Germany, changed in the course of globalisation and free movement within the EU and that new paths arose and influenced migration targets.

3. Last but not least, the question occurred, in the context of a job search, do highly-skilled workers use informal networks within their own country and EU-wide? This question was asked against the background of the assumption that, in contrast to the past, (migration) social networks may no longer play an important role in job searching within a country and abroad, (Granovetter, 1995). This stemmed from the belief that global flows and the lower restrictions of movement make job searching easier within the EU and that highly-skilled graduates are more independent and less reliant on networks.

\section{Theoretical Framework}

\subsection{Migration-A Regular Fluent Phenomenon}

It is differentiated between three levels of migration theories: macro-level, meso-level and micro-level (Mester, 2000). In the focus of many economic, geographical as well as sociological and anthropological migration theories the question of migration motives is raised on all these levels. Many scientists feel out the "why" of human migration. They also 
pose the question of why some population groups are more motivated to migrate than others. It is clear that migration is seldom an individual decision. In most cases, migration follows a chain process and is embedded in a broader social frame. Moreover, only in rare cases does migration mean a complete giving-up of domestic roots and full integration into the receiving country's society. This is even more strongly determined by faster mobility possibilities, new technology and faster communication. Today migration goes hand in hand with transnational lifestyles and identities (Schmitz, 2013; Schmiz, 2011). Being regarded as a social and active action, migration is never stable. It follows manifold dynamics and mechanisms (Castles et al., 2014). Migration changes in terms of destinations, distances, duration, social circumstances and further factors. Difficulties can be exacerbated by complex global developments. Furthermore, access to education and information, to social capital and financial resources increases people's aspirations to migrate (Castles et al., 2014). In comparison to former times, current migrants are freer in their choices. They do not have to depend on the second-hand experiences of close friends and family members, who were the pioneers of migration, but can also, inform those using e.g. further social networks.

As previously stated, migration is fluent. In other words, it shows some regularity, which cannot be completely examined and answered by one theoretical strand. There are theories which deal with different aspects of migration based on different assumptions. One theory may try to explain migration through economic factors only (the traditional view on migration), while another may place it under conditions of poverty and historical disequilibria of countries (Castles et al.; 2014). Others look at migration from a social perspective which treats migrants as economic drivers and innovators. In order to approach the "why" question and to pursue the main aim of this survey, in which the migration motives of highly-skilled graduates are traced, a reference to traditional migration theories is made in the following. Given the large number of migration theories, the present article refers to the main theories being in line with the accomplished survey.

\subsection{Migration - An Active Social Performance}

The first migration theories were already being discussed in the late 1880s. For instance, Ravenstein (1889) considered migration as economically driven. Today, the known migration theories can be summarized into different categories. The first category of migration theories reflects migration as a rather passive, rational and calculated choice and process of an individual. The individual is mainly described as economically motivated, weighing up the pros and cons of migration on the basis of a clear financial benefit. Most of the economically driven theories refer to macro and meso-levels of migration research. They try to explain migration using external factors such as regional disequilibria in relation to economy, labour, wages, governments, poverty etc. (Castles et al., 2014). Following this argumentation, it was Lee (1966), who argued that migration decisions are determined by "plus" and "minus" factors in the domestic and the receiving countries (Castles et al., 2014). Through this, Lee developed the push-pull model of migration, which is still of importance. With regard to migration of highly-skilled workers, the push-pull model is explained by Hunger (2003) as follows: the push-pull approaches of migration research are a first path to analyse the complex phenomenon of highly qualified migration. Push and pull factors mainly are analysed from a macro-theoretical point of view taking into consideration structural factors. Kalter (2000) takes up the position that the "push-pull paradigm" is not an independent theoretical model. In his view, it is rather a conviction that in the place of origin "repulsive" and in the destination place "attractive" conditions dominate. Moreover, the "push-pull model" was often criticised for its broad list of pushing and pulling factors in one country such as wages, labour markets, climate, political and social situation etc. Today, research shows that these are factors named on the macro, and in best case the meso-level. There are certainly a high number of personal reasons, which constitute a migration decision.

The functionalistic and neoclassical theories consider migration as a development process, by which the overflow of human capital (mainly) in the rural sector provides urban industrial areas with workforce (Lewis, 1954). Similar to the "push-pull model", it is the difference between the low-wage, labour-surplus regions, which encourage workers to move to high-wage, labour-scarce regions (Castles et al., 2014). At micro-level, neoclassical theories regard migrants as rational actors, who make decisions on the basis of a cost-benefit calculation. At macro-level, these theories view migration as a process in optimising the allocation of migration factors (Castles at al. 2014:30). In 1962 Sjaastad saw migration as an investment in increasing regional human capital, which he regarded as individual knowledge and skills. People invest in migration as in e.g. education. The better migrants' individual skills are, the more migration benefits. Bauer and Zimmermann cite that the "(d)ifferences in such expected "returns on investments" can partly explain why the young and the higher-skilled tend to migrate more" (1998:99 in e.g. Castles at al. 2014). The main criticism of these theories is that migrants are regarded as independent entities without social networks which had provided them with further motivation to make a migration decision. Furthermore, factors such as age, gender, knowledge, perceptions and attitudes to the outside world are not taken into close consideration. Thus, the exogenous factors play a bigger role than the endogenous.

Since the 1970s, historical-structural theories, including that developed by Massey et al. (1998), characterise migration 
by the many manifestations of capitalist penetration and the inequality of trade between developed and underdeveloped countries. Castles et al. (2014) state that the main difference between neoclassical and historical-structural migration theories is, that while the first regard migration as a voluntary process, the latter describe migration as a large-scale recruitment of workforce. In other words, the historical-structural theories argue that people are forced to migrate by outward traditional disequilibrium. The initial point of these theories sees an unequal distribution among countries and restrictions in the entrance of people to different sources such as education, labour markets etc. (Castles et al., 2014). Following this argumentation, the globalisation theory, developed in the 1990s, also considers migration as broader interconnection between societies, including all possible cross-border flows such as financial, human resources, knowledge etc. The effects of globalisation are heterogeneous. On the one hand, globalisation means the approach of various regions and cultures and their inclusion. On the other hand, globalisation means a greater exclusion of certain social groups by the restructuring of economies, which in some regions results in a lack of working possibilities thereby fostering migration. These theories provide a view of migrants as victims of globalisation and migration (Castles et al., 2014). All these theories, which mostly consider the macro and meso-level of migration, seem to be too narrow to understand migration motivation. They concentrate too much on political, environmental and predominantly, economic structures and too little on humans as migration actors.

A further category defines migration choice as a much broader action which takes place in social frames built up by families, friends, and colleagues and other significant actors such as pioneer migrants. In addition, it regards migrants not as victims of a system or injustice, but rather as social actors taking an active part in the decision-making towards a migration performance. This includes the idea that migration is a choice not taken by an individual in isolation but by an individual integrated into a social structure and at the same time building new social structures or even social capital. In following this idea, the household approach, the migration network theory, transnationalism (Pries, 2013) and the diaspora theories (Charim \& Auer Borea, 2012) can be listed. The household theory for instance, provides insight into how migrants actively try to use a migration process to overcome structural changes and social exclusion in their domestic countries. In many cases, a family chooses to support one of its members in migration to increase the income and status of the whole family in the domestic country by e.g. remittances. This often helps to overcome crises in the homeland (Massey at al., 1987). The migration network theory pushes social networks into the spotlight and explains how migrants build social ties (Granovetter, 1973) using them later for further migration processes, which can be seen as a path dependence (Pries, 2001). Such networks even create social, financial and human capital for both the domestic and receiving country by helping further recruitment of (in our case) a highly-skilled workforce. The effects of expanding globalisation, which go hand in hand with increasingly fast flows of finances, knowledge, movement, technology etc. and based on the migration network theory, transnationalism (Pries, 2013) and diaspora (Charim \& Auer Borea, 2012) theories have occurred. In contrast to migration networks, transnational networks are often long-distance connections improved by new and faster technology development. Furthermore, transnational networks are not only social ties between the domestic and receiving country, but may emerge between several receiving countries. "New Nomads" for instance, are highly-skilled and move between several receiving countries in their work context creating social ties. Transnational networks are often economically oriented. Knowledge and financial flows can be well-organised in such networks. Transnational migrants often develop a multilayer identity by operating in several countries at the same time and being a node in a transnational network connecting various actors. Diaspora can be outlined in a similar way. In the past diaspora was used in a new context of migration (Charim \& Auer Borea, 2012) and was closely related to migrants who involuntarily and under force, or as refugees, left their domestic countries. Today it participates even more in the identity formation of migrants (Castles et al., 2014). All these theories take into consideration the meso-level of migration and bring a close understanding of how social frames and contexts should be necessarily a part of the consideration of a migration process.

These and further migration theories contribute significantly to the "why" of migration. They provide insights at both macro and meso-levels by explaining the political, governmental, global and social circumstances of migration. The different theories lead to different views and ideas on migration. Not all can be bound to one overall theory. A main point of this article is to contribute to the micro-level of migration by interviewing highly-skilled graduates. The results of the survey presented here will later be set into a broader context of migration processes while taking into consideration macro and meso-levels.

\section{Method}

\subsection{Introduction to the Survey}

Labour migration involves two main categories of migrants:

1. The first category mainly comprises low-skilled workers (wageworkers, workers and job seekers), i.e. the most vulnerable people with regard to poverty and those who have the most difficulties in finding jobs. This refers 
particularly to people who have completed vocational training and are employed in lowly-qualified and low-paid work with benefits rarely provided, or unwillingly provided, by the local labour force. They compete for work with the residents of the respective country or with new migrants from their home country or other countries of emigration. With a view to migration flows in Europe from industrialisation up until the 1990s, it was mainly lowly-qualified migrants who decided to emigrate because of the economic situation in their home countries as well as structural compulsions.

2. The second group of migrant workers comprises well-qualified or highly-skilled people (mostly university graduates), including people with entrepreneurial spirit and high self-esteem. This group also includes frustrated and disappointed highly-qualified workers who move abroad because of non-existing job or career opportunities at home. Often their movement is effected by a hope of more challenging or better paid employment. They are characterised in many cases by having a great interest in professional development (Barwińska-Małajowicz, 2011). The "(...) increasing levels of education and occupational specialisation generate migration of people who seek to match their particular skills and preferences to particular jobs." (Castles at al. 2014:50).

Why the interest in the migration of highly-skilled between Poland and Germany? In recent years, the migration of (highly) skilled-workers has become a matter of intense discussion. Highly-skilled workers aged 25-29 have been over represented since 2004 and subsequent years in migration processes between Poland and Germany (Kaczmarczyk, 2008). Currently, an increasing number of students opt for studies abroad and search for an entry into professional careers in their destination country. The issue of highly-skilled migration is becoming more popular due to the current economic and financial crisis. This is reflected in high unemployment rates and growing youth unemployment in several parts of Europe (Spain, France, Italy, Poland, Romania etc.). Secondly, highly-skilled migration is at the fore of discussions about skills shortages in Europe. Despite high unemployment rates, some European labour markets are characterised by a simultaneous shortage of skilled workforce and highly-skilled workers. Both phenomena evoked a paradigm shift in the assessment of human labour, which has been determined by shortages in human resources (HR) and in workplace relocation in low-wage countries. Today, human capital comes more to the fore and again is given high priority in discussions regarding regional innovation systems and their knowledge base. Many regions are in international competition concerning "the smartest brains". Therefore, the exchange of a (highly-) qualified workforce is becoming more important for economic development. Hunger (2003) argues that knowledge becomes an engine of growth for economies and so demand for mobile and well-skilled workforces rises at international level. The management of cultural diversity can be an innovation potential for modern immigration societies. Furthermore, authors such as Faggian \& McCann (2009) point out the need for external knowledge for regional knowledge bases and ensuing innovation systems. It is not only regionally generated and anchored knowledge which plays an important part in innovation systems, but also new external knowledge. Knowledge exchange between regions and systems can evoke innovations. In this process, mobile highly-skilled workers are considered as a possible source (pipeline) (Bathel et al., 2004) able to transport knowledge between regions and lead to an interregional knowledge exchange. In this context, authors like Saxenian (2007) and Klagge \& Klein-Hitpaß (2010) pointed out in several studies on return migration how knowledge of the origin region alongside newly gained knowledge in the destination region can merge into innovative ideas thus leading to a positive boost of regional economy after their return. Competition for specific knowledge, which is generated or transported by highly-skilled workers, has been known in the literature for some time as the so-called "brain gain", "brain drain" or "brain circulation" concepts. Because of this, countries or regions promote the soft (culture and education) and hard (good infrastructure, jobs and workplaces) factors of location and attractiveness which are of benefit to well-qualified people, highly-skilled and skilled workers with the intention of persuading them to take part in interregional and international migration. In this way, they are using many measures and instruments to attract human capital. In this context, the findings of the study presented here and accomplished at micro-level, also contribute to regional attraction policy in that they present the possible motives of graduates and their real interest in migration.

\subsection{Research Design}

The survey presented here deals with possible motives for migration which favour labour driven migration. The views presented are those of a group of highly-skilled university graduates. The survey's empirical material is based on a standardised qualitative questionnaire distributed to Polish and German students shortly before their graduation as well as to graduates from public universities in two partner cities, (Rzeszów, Poland and Bielefeld, Germany). The aim of the questionnaire was to find out how, based on the graduates' prospects, personal motives led to labour driven migration. The survey was conducted with university graduates, as well as students in their final semester in various disciplines, at the University of Bielefeld, the Bielefeld University of Applied Sciences, the University of Rzeszów and the Rzeszów Technical University of Applied Sciences. A total of 439 participants from Bielefeld (Germany) and 402 from Rzeszów (Poland) took part in the survey. The groups of respondents were addressed with identical questionnaires, which primarily dealt with possible migration motives based on previous literature analysis. Thus, the majority of possible answers were given. In another part of the survey, the preferred destination countries of potential emigrants (in the case 
of possible migration) were asked for. A further important requirement was to obtain insights into the question of which form of recruitment graduates wishing to migrate would choose. Would they prefer to use informal national networks or EU wide networks? This question was to examine the idea of whether social networks are still of importance to those planning migration and whether they are linked to job searches.

\section{Results}

The main question of the survey addressed possible circumstances as well as the motivation for international labour migration. The group of graduates and final semester students answered this question. Every response option was evaluated in the categories "yes" or "no". The distribution of Bielefeld graduate responds shows the following picture: the achievement of a higher salary outside of Germany was named as one of the most irrelevant reasons for labour migration among the available response options (even though this reason was significant for more than the half). As motivators for labour related international emigration the following answers were chosen very often:

The perspective of the acquisition or better command of the target country's language (74\%), the possibility of better professional development abroad (73\%), the possibility of a common movement abroad with family (72\%), a lack of alternative income source options at home (71\%) (cf. figure 1). The majority of Rzeszów interviewees (72\%), when answering the same question, stated that they would emigrate if conditions allowed them learn the destination country's language. This leads to the hypothesis that young, educated people strive for further and new intellectual development and are willing to advance their learning as well as deepening their knowledge of foreign languages. It is striking that for less than half of the interviewees (47\%), a lack of alternative possibilities for taking care of their own subsistence was named as a motivational circumstance or factor. This distribution of responses can serve as a base material for carrying out more in-depth research in the analysed field. Moreover, the distribution of answers reveals the importance of a higher salary in the target country than in the home country (60\% of interviewees). Other important factors are: the opportunity to move abroad with the family $(63 \%)$, the perspective of better professional development abroad than in the home country $(62 \%)$ and equal rights for native citizens and immigrants $(61 \%)$ (cf. figure 1 )

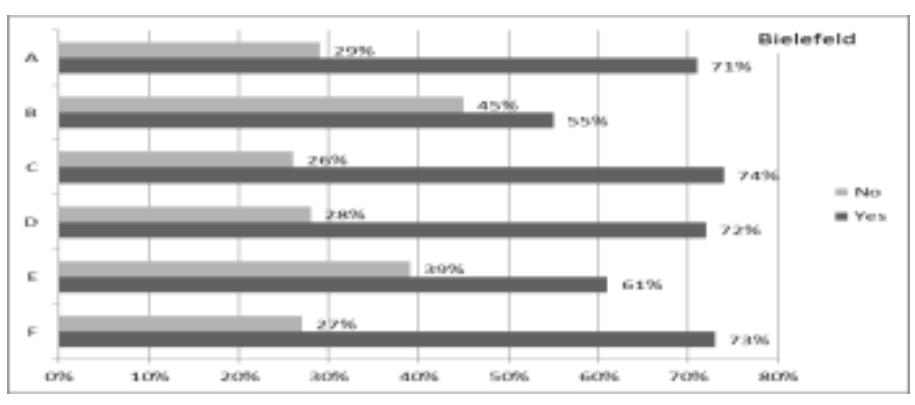

Figure 1. Circumstances that influence decisions about labour-related emigration in Bielefeld (GER)

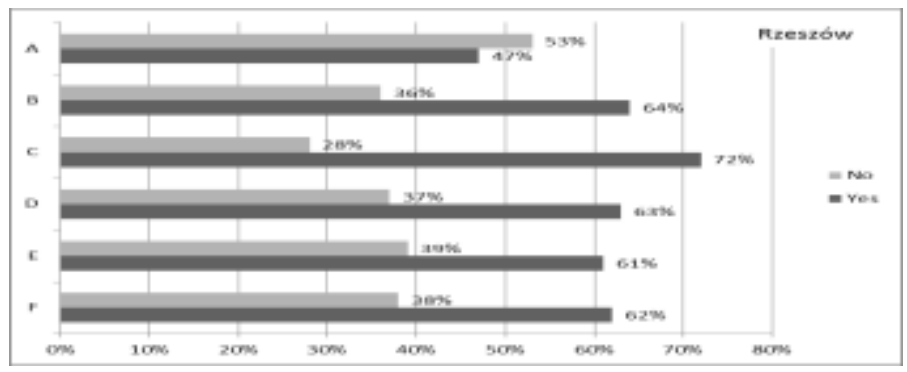

A - I see no other way to earn money, B - I would earn more money abroad, C - I could speak/learn a foreign language D - My family is moving abroad as well, E - I would have equal rights, as citizens of the country, F - I would have better career development chances and career opportunities than in the home country

Figure 2. Circumstances that influence decisions about labour-related emigration in Rzeszów (PL)

Source: 2010, own adaptation based on the survey

The survey also included the question: In which countries would you search for work? Here, the distribution of answers shows that the greater number of interviewed Bielefeld graduates would first look for employment in their home country (16\%), followed by Great Britain (14\%), the United States of America (13\%), the Netherlands (5\%) as well as France, Switzerland and Australia (each 4\%). Characteristic for this survey group were also responses without specifying a precise emigration place or destination, e.g. "Europe" (6\%), "everywhere" (3\%) (cf. figure 3). The majority of the interviewed graduation groups from Rzeszów planned in a similar way by searching in their homeland of Poland 
first (15\%). The following countries were also named as emigration destinations: Germany (13\%), USA (10\%), Great Britain and Ireland (each 8\%) and France and Norway (each $7 \%$ ) (cf. figure 4). Among other countries the Netherlands, Spain, Finland and Belgium were named most often. It is noteworthy that, despite the financial crisis, each tenth interviewee would be willing to search for work in the USA. It can be assumed that this refers to the long-lasting tradition of labour emigration from the Carpathian area (Iglicka, 2008) to the United States of America and the associated origin of further migration networks coming from the Subcarpathian Voivodeship.

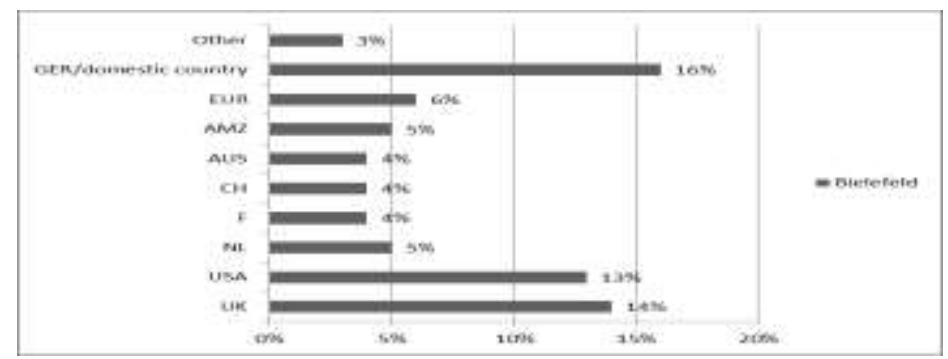

Figure 3. Stated direction of labour emigration from Bielefeld (GER)

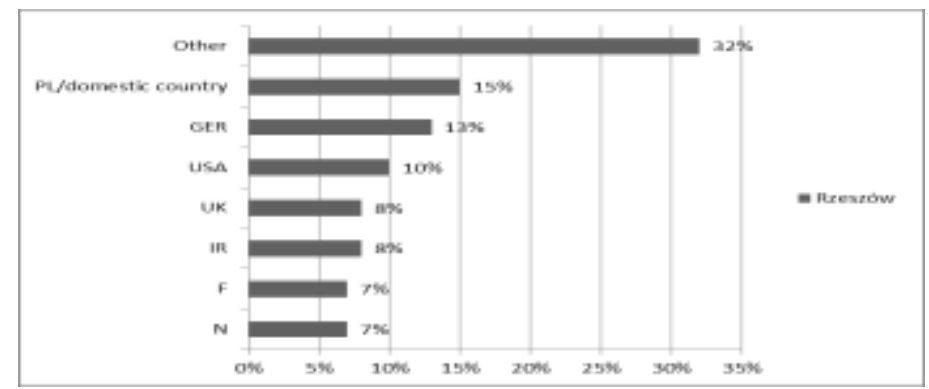

GER-Germany, UK-Great Britain, NL-the Netherlands, F-France, CH-Switzerland, AUS-Australia, AMZ-Central America, EUR-Europe, IR-Ireland, N-Norway, USA-United States of America

Figure 4. Stated direction of labour emigration from Rzeszów (PL)

Source: 2010, own adaptation based on the survey

The last important question in this context was whether the study participants would use informal social networks to help them find a job. The following question was asked: Would you use national or Europe-wide informal networks to find a job? Over $60 \%$ of the total interviewees underlined the importance of using both national and EU wide informal networks possibilities when searching for jobs. This implies that social informal networks still play an important role in searching for jobs at home or abroad.

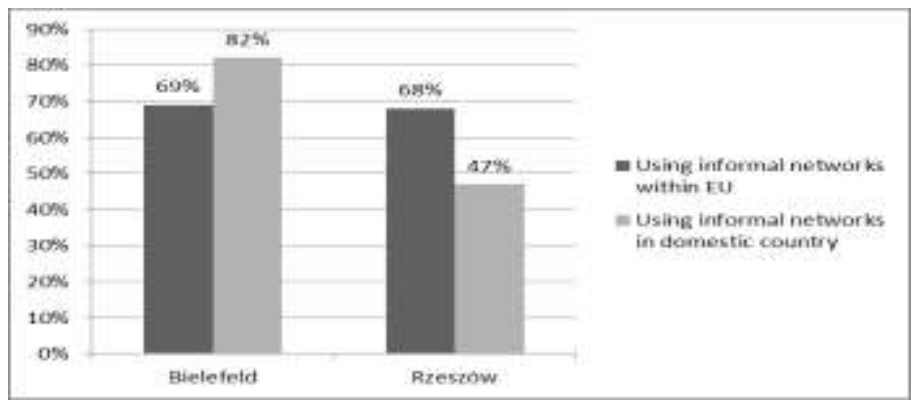

Figure 5. Use national or European wide informal networks to find a job

Source: 2010, own adaptation based on the survey

\section{Discussion}

The results of the present survey provide insights into the cause and motive research of high skills migration in both partner cities Bielefeld (Germany) and Rzeszów (Poland). These will be discussed in the following:

Taking into consideration the first question (Have migration motives changed, especially in the case of highly-skilled workers, and does migration remain largely driven by economics?), the survey showed a differentiated picture. 
Pallaske's (2001a, 2001b) study of labour migration among low-skilled workers found that a lack of perspective in migrants' home countries was the main motive for leaving. However, in this study, we found that a lack of perspective was not a reason for highly-skilled workers to want to emigrate. The results do not match with the respondents from Bielefeld, which is perhaps understandable due to Germany's solid economic situation, nor surprisingly, did they match with the Polish graduates from Rzeszów. At first glance, this outcome could possess a key differentiator of the former, purely economically-motivated migration patterns of low-skilled workers (Pallaske 2001a, 2001b). Kaczmarczyk (2008) attempts to explain the phenomenon by arguing that, although many Poles still see few perspectives in their home country, they do not see this as a radical fact. Compared to the past, they now see temporary labour migration, which lasts several weeks or months, as a fast solution and do not take permanent emigration into account anymore. However, the survey also illustrates that although the perspective of employment abroad does not initially reflect an increased motivation towards migration among Polish graduates, higher salaries abroad in comparison to Poland continue to be highly motivating. This is also stressed by Kaczmarczyk (2007), who sees it as the main motivation for a change from permanent to temporary migration. He names salaries and the cost of living differences between the home and the destination country, which are advantageous for migrants who earn money abroad and send it home. Their families stay in the home country and the emigrant returns home after a short period of being abroad. Kaczmarczyk (2007) cites the ease of transport and communication channels and open borders within Europe, the move towards commuting migration (circulating migration) and temporary work extensions, as the Polish trend of unemployment export. The responses of the graduates of both countries clearly show that the demands on migration, and therefore on the destination country and region, have changed. A stay in a foreign country does not seem to serve the purposes of a single economic acquisition anymore; moreover, the opportunity to acquire another language is becoming more important. This could possibly be another differentiator to previous migration patterns. It also confirms the global development and economically motivated competition, which nowadays requires an international orientation of a highly-skilled workforce. This is reflected by being competent and fluent in many languages. But is migration really no longer being seen as just an economic necessity? Taking a closer look at the motives, which are mainly a chance for professional development in the sense of lifelong learning, it could be assumed that today's highly-skilled workers are not economically driven in their migration choice. This closer examination has allowed the authors to form the opinion that the migration of highly-skilled workers is still a matter of economics. The identified answer does not exactly point to economic motivation, but motives such as the acquisition of foreign languages, obtaining citizens' rights in a foreign country and having better carrier opportunities imply a motivation driven by economics. Acquisition of new skills and the internationalization and transnationalisation of personality are often concomitant with hopes for an improved individual economic standard. In a global world, where the highly-skilled are seen as drivers of knowledge creation and innovation and as representatives of international spirit and openness, the knowledge of many cultures and foreign languages offer myriad international opportunities for young, skilled people to earn "good" money and attain high positions in the labour market. In summarising, it seems as if the "new" motives for migration are not new at all. Rather, they are economically-driven motives placed under a new spotlight.

With regard to the second question (Do highly-skilled migrants choose new emigration destinations first or do they still use historical pathways to find jobs?), the following picture emerged:

The survey shows that graduates from Bielefeld and Rzeszów tend to choose their domestic country first in their search for jobs. A survey undertaken by the Institute for Work and Technology (IAT) on "MINT" graduates in North-Rhine Westphalia (NRW) (Leisering \& Rolff, 2012) pointed out that their place of study or place of birth held the highest attraction for graduates and that this also applied to future job searches and ideas for shaping their lives. The survey results, and of further studies, refers to the fact that highly-skilled workers are not as mobile as had been previously assumed. This reduces countries' and regions' recruitment opportunities of (highly)-skilled workforces. In taking further answers from the Bielefeld graduates into consideration, it is clear that they favour the UK and USA as prime emigration destinations when looking for jobs. Both countries are English-speaking and as almost all graduates in Germany possess a good command of English, they feel more secure choosing a destination country with a language they already know. In addition, the USA has a long German emigration tradition being perceived by Germans as the most innovative country (e.g. Silicon Valley). Working in the USA is highly regarded and with its research and technology-driven communities, is seen as the prime place to learn and to develop an innovative and entrepreneurial spirit. Looking at the answers given by Polish graduates from Rzeszów, Germany and the USA are named as the most favourable countries for emigration and finding jobs. We know from the migration literature that the Carpathian Voivodeship has a long history of migration to the USA which originates from before the Polish Transformation. Only people from a few Polish regions, such as Masuria and Silesia, were accepted in Germany becoming known as re-settlers. Therefore, the only way for people from other Polish regions to escape the regime was to choose non-European destinations. The survey presents possible indicators of old migration networks from Rzeszów to the USA. An explanation for Germany being listed as the second most favoured destination for emigrants might be found in 
the new migration patterns. The paper discusses how circular and short-term migration appears to be a better option for several of the highly-skilled migrants to earn money. Germany is seen to have a stable economy and shares a border with Poland leading to the assumption that migrants willingly choose Germany as a destination for migration. It is the short distance between the two countries which encourages the circular migration of highly-skilled migrants.

Answering the questions step by step leads us to the last one on the usage of informal networks within migrants' home countries, or within Europe, in terms of searching for jobs.

Both Bielefeld and Rzeszów graduates stated that informal (migration) social networks are still important in searching for jobs. The broad literature on (migration) networks (David \& Coenen 2014, Pries, 2001) shows that formal, and especially informal, networks still are of immense importance. In the case of labour migration they can function as a door opener in the receiving countries. With regard to highly-skilled workers, networks are not only family and friends-related. In many cases it is business networks which provide individuals with job offers in destination countries.

\section{Conclusion}

To be competitive in the global economic process Europe needs to tackle several challenges simultaneously. On the one hand, there is the high level of youth unemployment resulting in missing perspectives for an entire generation and on the other hand, there is the search for an appropriately (highly)-skilled workforce. These challenges need to be addressed not only because of the financial and economic crises but also because of phenomena such as demographic change. It is human capital, anchored in university graduates, that represents the knowledge base, and thus the competitiveness, of a region and a country. This knowledge, held by university graduates, is what regional economies need to look for. Due to freedom of workers' movement and the opening of borders, flexible and highly-skilled workers exist who are ready to take their chances in those places which offer them the most to enhance their future careers. This paper deals with questions about the motivation of graduates in the cities of Bielefeld (Germany) and Rzeszów (Poland) in relation to international labour migration. The results of the study indicate that migration motives could have changed within recent years, and that there are differences between low-skilled and highly-skilled workers. Today's labour migration of graduates still seems to be motivated by socio-economic reasons, but also asks for professional and personal advancement in terms of lifelong learning. The influences of globalisation are becoming more obvious through the orientation and pursuit of international standards (the learning of foreign languages indicates such a development). The German-Polish comparison also points out that the mismatch between salaries in east and west is still a push-factor for Polish labour migration. Nevertheless, it can be stated that young, educated people also search for new careers abroad and are not only driven by economic factors. The present study also raises several questions that require further research. It would make sense to compare current migration motives, which have been increased by the crisis, with the migration motives of graduates in the past. Also, further differences between the motivation of low-skilled and highly-skilled workforces could be analysed. From a regional perspective, the results should be examined in depth because regions are seeking suitable workforces. If more in-depth knowledge of the migration motives of highly-skilled labour migrants was available, current regional information could be tailored to the attracted target groups. This is important because knowledge of the individual motives of highly-skilled workers would allow countries and regions to put incentives in place to attract the workers they want and need, e.g. faster recognition of qualifications, good job opportunities and an open international environment brought about by a positive and welcoming culture.

As the study shows, the fact that networks still play an important role in job searching and the migration process, could also be used by countries and regions as an attraction factor. Regional migration-related networks such as diaspora, alumni networks (networks for highly-skilled graduates), company networks etc. could be instrumentalised for the recruitment of new skilled workforces from abroad. In following this theme, the study contributes with first insights into a broad and future-oriented topic. It completes with its micro-level in contrast_to the aforementioned macro and meso-level theories and by doing so, the present survey is a step further towards a better understanding of migration.

\section{Acknowledgements}

The investigations were carried out by A. Barwińska-Małajowicz in the academic year 2008/2009 and were continued by her in 2009/2010. Respondents included students nearing the end of their university studies and public universities graduates in the partner cities of Rzeszów (Poland) and Bielefeld (Germany). A query served as a source of information in which the survey types: closed, half-open, open and conjunctive were used. The questionnaire was divided in nine chapters and included 42 questions.

\section{References}

Bade, K. (2003). Migration in European history. Oxford: Blackwells. http://dx.doi.org/10.1002/9780470754658 
Bauer, T., \& Zimmermann, K. F. (1998). Causes of international migration: a survey. In P. Gorter, P. Nijkamp \& J. Poot (Ed.), Crossing borders: regional and urban perspective on international migration. (pp. 95-127). Aldershot. Bähr, J. (1983). Bevölkerungsgeographie. Stuttgart.

Barwińska-Małajowicz, A. (2011). Einstellungen von Studenten und Absolventen von Hochschulen im Kontext des internationalen Durchflusses von hochqualifizierten Mitarbeitern. Der Fall der Partnerstädte Rzeszów-Bielefeld, In Osteuropa. Wirtschaft, 56(3-4) (pp. 99-100), Berlin.

Barwinska-Malajowicz, A., Puchalska, K. (2010): Międzynarodowe przepływy kapitału i siły roboczej, Wyd. UR, Rzeszów, S. 95.

Bathel, H.; Malmberg, A., \& Maskell, P. (2004). Clusters and knowledge: local buzz, global pipelines and the process of knowledge creation. Progress in Human Geography, 28(1), 31-56. http://dx.doi.org/10.1191/0309132504ph469oa

Castles, S.; De Haas, H.; \& Miller, M. J. (2014). The age of migration: international population movements in the modern world ( $5^{\text {th }}$ Edition). Basingstoke: Palgrave Macmillan.

Castles, S., \& Miller, M. J. (2009). The age of migration: international population movements in the modern world $\left(4^{\text {th }}\right.$ Edition). Basingstoke: Palgrave Macmillan.

Charim, I., \& Borea, A. G. (2012). Lebensmodel Diaspora. Über moderne Nomaden. Bielefeld: transcript Verlag. http://dx.doi.org/10.14361/transcript.9783839418727

David, A., Barwinska-Malajowicz, A., \& Coenen, F. (2012). From brain drain to brain exchange: how to use better highly skilled workers; a conceptual approach. Unia Europejska.pl, 216(5), 25-35.

David, A., \& Coenen, F. (2014). Alumni networks - An untapped potential to gain and retain highly-skilled workers? Higher Education Studies, 4(5), 1-17. http://dx.doi.org/10.5539/hes.v4n5p1

Faggian, A., \& McCann, P. (2009). Human capital, graduate migration and innovation in British regions. Cambridge Journal of Economics, 33, 317-333. http://dx.doi.org/10.1093/cje/ben042

Faist, T. (2007). Migrants as transnational development agents: an inquiry into the newest round of the migration-development nexus. Population, Space and Place, 14(1), 21-42. http://dx.doi.org/10.1002/psp.471

Florida, R. (2008). Who's your city? How creative economy is making where to live the most important decision of your life. New York: Basic Books.

für Theorien der Arbeitsmigration. In T. Geisen (Ed.), Arbeitsmigration. WanderarbeiterInnen auf dem Weltmarkt für Arbeitskraft. (pp. 52-53), Frankfurt am Main.

Gans, P.; Lang, Ch., \& Pott, A. (2013). Bevölkerungsdynamik und Migration. In H. Gebhardt; R. Glaser \& S. Lentz (Ed.), Europa-eine Geographie (pp. 329-377). Berlin Heidelberg. http://dx.doi.org/10.1007/978-3-8274-2720-5_6

Granovetter, M. S. (1995). Getting a job: a study of contacts and careers. Chicago: University of Chicago Press.

Granovetter, M. S. (1973). The strength oft he weak ties. The American Journal of Sociology, 78(6), 1360-1380. http://dx.doi.org/10.1086/225469

Haisch, T., \& Klöpper, Ch. (2014). Location choices of the creative class: does tolerance make a difference? Journal of Urban Affairs, OO(0), 1-22. https://dx.doi.org/10.1111/juaf.12148

Haug, S. (2008). Migration networks and migration decision-making. Journal of Ethic and Migration Studies, 34(4), 585-605. http://dx.doi.org/10.1080/13691830801961597

Hunger, U. (2003). Vom Brain Drain zum Brain Gain: die Auswirkungen der Migration von Hochqualifizierten auf Abgabe- und Aufnahmeländer, Wirtschafts- und Sozialpolitischen Forschungs- und Beratungszentrum der Friedrich-Ebert-Stiftung, Abteilung Arbeit und Sozialpolitik, Bonn.

Hunger, U. (2003). Wirtschafts- und Sozialpolitisches Forschungs- und Beratungszentrum, Gesprächskreis Migration und Integration, Wirtschafts- und Sozialpolitischen Forschungs- und Beratungszentrum der Friedrich-Ebert-Stiftung, Abteilung Arbeit und Sozialpolitik, Bonn.

Iglicka, K. (2008): Wizy do USA. Mity, fakty, rekomendacje, Monitoring polskiej polityki zagranicznej, Centrum Stosunków Międzynarodowych, Warszawa, S. 6. In die USA wandern vorwiegend die Einwohner von drei Woiwodschaften aus: Kleinpolen, Karpatenvorland und Podlachien.

Kaczmarczyk, P. (2007): Arbeitskraftwanderung aus Polen-Die Erwartungen vor und die Realität nach der EU-Osterweiterung. In M. Nowicka (Ed.), Von Polen nach Deutschland und zurück. Die Arbeitsmigration und ihre Herausforderung für Europa (p. 99 ff). Bielefeld. 
Kaczmarczyk, P. (2008): Arbeitsmigration und der polnische Arbeitsmarkt. Working Paper: Die Zukunft des Europäischen Wirtschafts- und Sozialmodells.

Kalter, F. (2000). Theorien der Migration. In A. Diekmann, U. Mueller \& Nauck, B. (Ed.), Handbuch der Demographie 1. Modelle und Methoden. (p. 447). Heidelberg. http://dx.doi.org/10.1007/978-3-642-57097-1_9

Klagge B., \& Klein-Hitpaß, K. (2010). High-skilled return migration and knowledge-based development in Poland. European Planning Studies, 18(10), 1632-1651. http://dx.doi.org/10.1080/09654313.2010.504346

King, R. (1978). Return migration: A neglected aspect of population geography. The Royal Geographical Society Area, 10(3), 175-182 (with the Institute of British Geographers).

Köhnert, Steffen (2007): Migrationstheorien, Internetdokument.

Lee, E. S. (1966): A theory of migration. Demography, 5(1), 47-57; and in J. A. Jackson (Ed.): Migration. Cambridge: Cambridge University Press, 1969, (pp. 282-297).

Leisering, B., Rolff, K. (2012): Was bindet junge Akademiker an Arbeitsplätze in der Region? Ergebnisse einer Online-Umfrage bei MINT-Studierenden in NRW. Internet-Dokument. Gelsenkirchen: Inst. Arbeit und Technik. Forschung Aktuell, Nr. 03/2012.

Lewis, W. A. (1954). Economic development with unlimited suppliers of labour. Manchester School of Economic and Social Studies, 22, 139-191. http://dx.doi.org/10.1111/j.1467-9957.1954.tb00021.x

Mester, F. (2000). Zuwanderungen in die Länder der Europäischen Union: Bestimmungsgründe, Folgen und migrationspolitische Implikationen, Beitraege zum Siedlungs- und Wohnungswesen und zur Raumplanung, Band 192, (p. 83) Institut für Siedlungs- und Wohnungswesen, Münster.

Massey, D. S., Durant, J., \& Malone, N. J. (2002). Beyond smoke and mirrors: Mexican immigration in an era of economic integration. New York: Russell Sage Foundation.

Nowicka, M. (2007). Von Polen nach Deutschland und zurück. Die Arbeitsmigration und ihre Herausforderung für Europa. Bielefeld: transcript Verlag.

OECD (2014). International migration outlook 2014. OECD Publishing. http://dx.doi.org/10.1787/migr_outlook-2014-en

OECD (2013). International migration outlook 2013. OECD Publishing. http://dx.doi.org/10.1787/migr_outlook-2013-en

OECD (2008). The global competition for talent. Mobility of highly skilled. OECD Publishing.

Pallaske, C. (2001a). Die Migration von Polen nach Deutschland. Zu Geschichte und Gegenwart eines europäischen Migrationssystems. Baden-Baden: Nomos Verlagsgesellschaft.

Pallaske, C. (2001b). Die Migration aus Polen in die Bundesrepublik Deutschland in den 1980er und 1990er Jahren. In Ch. Pallaske (Ed.), Die Migration von Polen nach Deutschland. Zu Geschichte und Gegenwart eines europäischen Migrationssystems (pp. 123-140). Baden-Baden.

Pries, L. (2001). Internationale Migration. Bielefeld: transcript Verlag.

Pries, L. (2013). Neue Dynamiken inter- und transnationaler Migration: Herausforderung für Wissenschaft und Politik. In B. Pusch (Ed.), Transnationale Migration am Beispiel Deutschland und Türkei (pp. 67-82). Wiesbanden. http://dx.doi.org/10.1111/j.1467-9957.1954.tb00021.x

Pöchhacker, Innovation Consulting GmbH (2009): Wie attraktiv ist Linz beziehungsweise Oberösterreich für internationale Spitzenkräfte?

Ravenstein, E. G. (1889). The laws of migration. Journal of the Royal Statistical Society, 52, 214-301.

Salt, J. (2009). Processes among the highly skilled in Europe. International Migration Review, 26(2), 484-505. http://dx.doi.org/10.2307/2547068

Sjaastad, A. H. (1962). The costs and return of human migration. Journal of Political Economy, 70(5), 80-93. http://dx.doi.org/10.1086/258726

Saxenian, A. (2007). The new argonauts: regional advantage in a global economy. Cambridge: Harvard University Press.

Schmitz, A. (2013). Transnational leben. Bildungserfolgreiche (Spät-) Aussiedler zwischen Deutschland und Russland. Bielefeld: transcript Verlag. http://dx.doi.org/10.14361/transcript.978389423288 
Schmiz, A. (2011). Transnationalität als Resource? Netzwerke vietnamischer Migrantinnen und Migranten zwischen Berlin und Vietnam. Bielefeld: transcript Verlag. http://dx.doi.org/10.14361/transcript.9783839417652

Stockhorst, J. (2011). Verfügbarkeit von hoch qualifizierten Arbeitskräften abseits von Ballungsräumen. Regionale Restriktionen und Chancen für Hochtechnologieunternehmen der Medizintechnik. Stadt und Regionalforschung. Berlin: LIT VERLAG, Dr. W. Hopf.

Tassinopoulos, A., Heinz, W. \& Kristensen, S. (1998). Mobility and migration of labour in the European Union and their specific implications for young people. CEDEFOP document.

Wagner, M., Fialkowska, K., Piechowska, M., \& Lukowski, L. (2013). Deutsches Waschpulver und polnische Wirtschaft. Die Lebenswelt polnischer Saisonarbeiter. Ethnographie Beobachtungen. Bielefeld: transcript Verlag.

Vorwiebe, R., Mau, S., Seidel, N., \& Kathmann, T. (2010). Skilled german migrants and their motives for migration within Europe. Int. Mingration \& Integration, 11, 273-293. https://dx.doi.ord/10.1007/s12134-010-0141-9

Yildiz, E. (2013). Die weltoffene Stadt. Wie Migration Globalisierung zum urbanen Alltag macht. Bielefeld: transcript Verlag. http://dx.doi.org/10.14361/transcript.9783839416747

$(c c) \overline{E Y}$

This work is licensed under a Creative Commons Attribution 3.0 License. 